\title{
Correction to: An approach to study the electrode-solution interfacial region. Direct vs. homogeneous electro-catalytic electrolysis, near-electrode tomography
}

\author{
Victor G. Mairanovsky ${ }^{1}$ \\ Published online: 4 December 2020 \\ (C) Springer-Verlag GmbH Germany, part of Springer Nature 2020
}

Correction to: Journal of Solid State Electrochemistry https://doi.org/10.1007/s10008-020-04652-9

The following footnote should be added in the published paper:

Dedicated to Professor Fritz Scholz, a scientist with the broadest horizons, on the occasion of his 65 th birthday.

The original article has been corrected.

Publisher's note Springer Nature remains neutral with regard to jurisdictional claims in published maps and institutional affiliations.

The online version of the original article can be found at https://doi.org/ 10.1007/s10008-020-04652-9

\footnotetext{
Victor G. Mairanovsky

vmairan@googlemail.com

1 Scientific Society WiGB, Berlin, Germany
} 